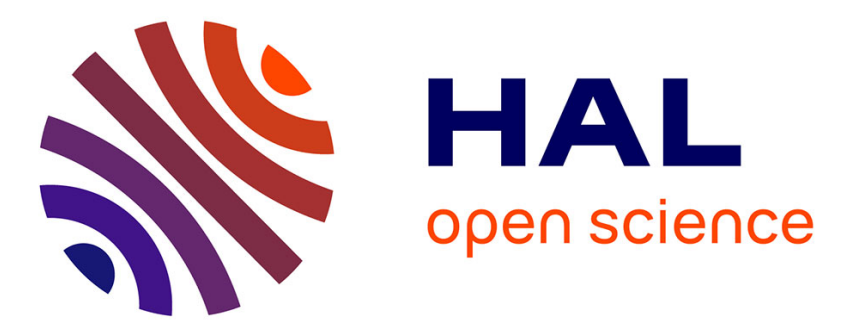

\title{
Development of Exon-Primed Intron-Crossing (EPIC) PCR primers for the malaria vector Anopheles pseudopunctipennis (Diptera: Culicidae)
}

Frédéric Lardeux, Claudia Aliaga, Rosenka Tejerina, Raul Ursic-Bedoya

\section{To cite this version:}

Frédéric Lardeux, Claudia Aliaga, Rosenka Tejerina, Raul Ursic-Bedoya. Development of Exon-Primed Intron-Crossing (EPIC) PCR primers for the malaria vector Anopheles pseudopunctipennis (Diptera: Culicidae). Comptes Rendus Biologies, 2012, 335 (6), pp.398-405. 10.1016/j.crvi.2012.05.002 . hal-01254144

HAL Id: hal-01254144

https://hal.science/hal-01254144

Submitted on 13 Jan 2016

HAL is a multi-disciplinary open access archive for the deposit and dissemination of scientific research documents, whether they are published or not. The documents may come from teaching and research institutions in France or abroad, or from public or private research centers.
L'archive ouverte pluridisciplinaire HAL, est destinée au dépôt et à la diffusion de documents scientifiques de niveau recherche, publiés ou non, émanant des établissements d'enseignement et de recherche français ou étrangers, des laboratoires publics ou privés. 
Development of Exon-Primed Intron-Crossing (EPIC) PCR Primers for the Malaria Vector Anopheles pseudopunctipennis (Diptera: Culicidae)

\section{Développement d'Amorces PCR Exon-Primed Intron-Crossing (EPIC) pour le vecteur de paludisme Anopheles pseudopunctipennis (Diptera: \\ Culicidae)}

Frédéric Lardeux, ${ }^{1,2, *}$ Claudia Aliaga, ${ }^{1,2}$ Rosenka Tejerina, ${ }^{1,2}$, Raùl Ursic-Bedoya ${ }^{3}$

${ }^{1}$ Institut de Recherche pour le Développement (IRD), C.P. 9214, La Paz, Bolivia

${ }^{2}$ Instituto Nacional de Laboratorios de Salud (INLASA), Laboratorio de Entomologia

Medica, Rafael Zubieta ${ }^{\circ}$ 1889, Casilla M-10019, Miraflores, La Paz, Bolivia

${ }^{3}$ Simon Fraser University, Department of Biological Sciences, 8888 University Dr., Burnaby, BC V5A1S6, Canada.

* Corresponding Author: IRD, C.P. 9214, La Paz, Bolivia.

e.mail: frederic.lardeux@ird.fr

Tel : $+591-2-2225280$

Fax : +591-2-278 2944 
RESUME Utilisant le génome d'Anopheles gambiae Giles comme modèle, nous avons identifié 14 nouvelles Exon-Primed Intron-Crossing (EPIC)-paires d'amorces PCR pour Anopheles pseudopunctipennis Theobald 1901, un vecteur majeur de Plasmodium sp. humains en Amérique du Sud. Ces amorces ont été conçues afin de cibler les régions conservées flanquant les exons consécutifs de différents gènes et ont permis l'amplification de 17 loci dont neuf étaient polymorphes. Le polymorphisme de ces loci varie de deux à quatre allèles. L'analyse du polymorphisme de longueur d'intron est un outil utile qui permettra l'étude de la structure de la population de cette espèce de moustique qui demeure mal comprise.

MOTS-CLES EPIC-PCR, Anopheles pseudopunctipennis, paludisme, amorce, intron

\begin{abstract}
Using the Anopheles gambiae Giles genome as a template, we designed, screened and identified 14 novel Exon-Primed Intron-Crossing (EPIC)- PCR primer pairs for Anopheles pseudopunctipennis Theobald 1901, a major vector of human Plasmodium sp. in South America. These primers were designed to target the conserved regions flanking consecutive exons of different genes and enabled the amplification of 17 loci of which nine were polymorphic. Polymorphisms at these loci ranged from two to four alleles. Intron length polymorphism analysis is a useful tool which will allow the study of the population structure of this mosquito species which remains poorly understood.
\end{abstract}

KEY WORDS EPIC-PCR, Anopheles pseudopunctipennis, malaria, primer, intron 


\section{Introduction}

The mosquito Anopheles pseudopunctipennis Theobald 1901 (Diptera: Culicidae) is a major vector of human Plasmodium sp. in South America. It is a difficult species to characterize as demonstrated by its variable behavior, habits and ecological needs [1], its inconsistencies as a malaria vector in its wide distribution range [2] and the several morphological sub-species described [3]. Crossmating experiments and cytogenetic pointed out evidence that these mosquitoes are comprised of a species complex $[4,5]$. Although the genetic variability and population structure of An. pseudopunctipennis has been studied biochemically, many aspects remain poorly known [6]. This species lacks specific molecular tools, and because of its high level of variability more data are urgently needed to better understand how the population genetic structure of this mosquito is related to malaria transmission. Such data will help to better target vector control strategies by Public Health authorities.

Variability of non coding sequences, particularly intron sequences, is a valuable marker of population variation and subdivision, and can be assayed by PCR amplification using conserved exon primers. Intron-targeted PCR was pioneered by [7]. This approach, called Exon-Primed Intron-Crossing (EPIC)-PCR [8, 9], has been shown identify substantial variability, mainly from intron length polymorphism. Intron constitute suitable markers for analyzing population structure within a species $[10,11,12,13,14,15]$ as well as for reconstructing relationships among closely related species $[16,17,18]$. EPICs have been also used in gene mapping [19, 20, 21, 22, 23], and phylogeography [24, 25, 26, 27, 28] where they are the most widely used nuclear markers for such studies [29]. EPIC-PCR has several advantages in populations genetic studies: (i) by using primers from heterologous genes, cloning and sequencing steps can be avoided [30, 31]; (ii) cross-species amplification is easier than when primers are designed from highly conserved exon sequences, (iii) for the same 
reason, within species, PCR artefacts such as null alleles are expected to be less frequent. Furthers advantages are that intron systems do not require previous knowledge of the genome to be analyzed; they are generally polymorphic and sometimes hypervariable; are expected to be codominant and selectively neutral; are easily amplifiable by PCR; can be revealed on simple agarose or acrylamide gels; and can be obtained at low cost [32]. Moreover, having both the exon and intron fragments, EPICs can be useful for examining genetic variation at the intraspecific and interspecific level simultaneously, a feature that is particularly useful when studying species complexes [27]. EPIC markers are becoming more popular for use in population genetic studies in insects $[13,14,15,33,34]$ and do not require assumptions about a particular model of evolution that is often required for microsatellites [14]. In the present paper, primers for EPIC amplification of intron sequences for An. pseudopunctipennis are designed, of which several pairs amplify (length)-polymorphic loci that can be used in population genetic studies of this malaria vector.

\section{Materials and methods}

\subsection{Mosquitoes}

In October 2006, females An. pseudopunctipennis were captured by one of us (FL) from a natural population in Mataral (S 18.6024, W 65.1444, altitude $1500 \mathrm{~m}$ ), a small village situated in the dry inter-Andean valleys in the centre of Bolivia, using human bait collection technique outside houses. In the field, collected insects were chloroform killed and stored over desiccant (silica gel) in small vials. In the laboratory, mosquitoes were identified using [35] and kept at $-20^{\circ} \mathrm{C}$ in their individual vials with silica gel until DNA extraction.

For the various EPIC-PCRs (see paragraph below), positive controls consisted in females An. gambiae from a laboratory strain and were provided by our main laboratory at IRD- 
Montpellier (France). These mosquitoes were stored using the same conditions as for An. pseudopunctipennis until processing.

\subsection{Selection of introns and design of primers}

Primers for An. pseudopunctipennis were designed from the conserved regions of consecutive exons of different genes from the closely related species Anopheles gambiae Giles. Exon sequences were downloaded in 2005 at http://www.anobase.com in Excel format from the An. gambiae genome database. Gene candidates that were dispersed amongst the An. gambiae genome were selected, and close genes on the same chromosome were avoided. Gene candidates with a higher percentage of similarity with genes from Diptera Apis mellifera and Drosophila melanogaster, were first selected to enhance the chance of similarity to genes from An. pseudopucntipennis.

Intron length's ranged from 100 to $500 \mathrm{bp}$. Primers pairs were designed to target the flanking exon sequences taking into account their stability (in terms of CG content and ending with CG or GC), their size (18-20 pb), their close annealing temperatures, and the low probability of primer-dimer formation during the PCR. Possible primers adjacent to the intron sequences were discarded. Fifty four primer pairs were initially designed and screened by PCR using An. pseudopunctipennis DNA as a template (Table 1).

\subsection{DNA extraction and amplification}

An. pseudopunctipennis and An. gambiae DNA extractions were carried out on mosquito legs using a slightly modified CTAB (cetyltrimethylammonium bromide) based protocol from [36]. The protocol was as followed: mosquito legs were homogenized in $200 \mu$ lysis CTAB solution $(100 \mathrm{mmol} / 1$ Tris $\mathrm{HCl} \mathrm{pH} 8.0 ; 10 \mathrm{mmol} / 1$ EDTA $\mathrm{pH} 8.0 ; 1.4 \mathrm{~mol} / \mathrm{l} \mathrm{NaCl}$ and CTAB $2 \%$ ) in $1.5 \mathrm{ml}$ Eppendorf microcentrifuge tubes. Incubation was carried out at $65^{\circ} \mathrm{C}$ for 15 
min; the resulting extract was washed with $200 \mu \mathrm{l}$ chloroform and centrifugated for $5 \mathrm{~min}$ at $12000 \mathrm{rpm}$. The supernatant was precipitated in $200 \mu 1$ isopropanol and centrifugated again at $12000 \mathrm{rpm}$ for $15 \mathrm{~min}$. The pellet was washed with $200 \mu 170 \%$ ethanol, centrifugated at $12000 \mathrm{rpm}$ for $5 \mathrm{~min}$, dried at $37^{\circ} \mathrm{C}$ for one hour and suspended in $100 \mu \mathrm{l}$ nuclease-free $\mathrm{H}_{2} 0$. DNA amplifications were carried out immediately after extraction in volumes of $25 \mu \mathrm{l}(1 \mathrm{xTaq}$ buffer, $2.5 \mathrm{mM} \mathrm{MgCl} 2,0.4 \mathrm{mM}$ dNTPs (Eurogentec, Angers, France), 0.5 UI Taq polymerase (Quiagen, Courtaboeuf, France), 20-25 ng of DNA template, and depending of the locus 0.04 $\mu \mathrm{M}$ or $0.4 \mu \mathrm{M}$ of each primer (Eurogentec, Angers, France) (Table 2). The optimum annealing temperatures for each primer pair are listed in Table 2. PCRs were performed on a Perkin Elmer DNA Thermal Cycler 480 (US Instrument Division, Norwalk, CT, USA) and conditions were: $1 \mathrm{~min}$ at $94^{\circ} \mathrm{C}$, followed by 36 cycles of $30 \mathrm{~s}$ at $94^{\circ} \mathrm{C}, 30 \mathrm{~s}$ at annealing temperature, $30 \mathrm{~s}$ at $72^{\circ} \mathrm{C}$, and a final extension step of $5 \mathrm{~min}$ at $72^{\circ} \mathrm{C}$. The amplified products were first visualized on 1.5\% agarose gels con ethidium bromide (Fig. 1.). Then, for allele size analysis, they were separated by electrophoresis on $8 \%$ polyacrylamide gels and visualized by silver-staining. In all PCR, negative control $\left(\mathrm{H}_{2} \mathrm{O}\right)$ and positive controls $(A n$. gambiae) were used.

\subsection{Data analysis}

Allele sizes were scored using the numerical procedure implemented in LabImage version 3.0 [37] using a size-standard $100 \mathrm{bp}$ gene ruler. Observed $\left(H_{O}\right)$ and expected heterozygosities $\left(H_{E}\right)$, the inbreeding coefficients (Fis statistics) and the $R^{2}$ coefficient to estimate linkage disequilibrium for each locus pairs were computed using procedures implemented in the GENETIX package [38].

\section{Results and Discussion}


Of the 54 selected pairs of primers, 14 pairs successfully amplified 17 loci (Table 2). All the 54 pairs of primers successfully amplified loci in An. gambiae. Forty pairs of primer did not amplify any loci in An. pseudopunctipennis while they did in An. gambiae. As an example, Fig. 1 presents results of agarose gel electrophoresis for four primers pairs. Fig 1a. shows positive amplifications in both An. pseudopunctipennis and An. gambiae while Fig. 1 b. gives examples of negative amplifications in An. pseudopunctipennis but positive ones in An. gambiae (positive controls). Because EPICs are universal primers they may amplify introns in other species. Table 3 is based on nucleotide BLAST (NCBI web site) of the 54 studied primers pairs and exhibits those that might amplify in a variety of other species including other mosquitoes (Aedes aegypti and Ae. albopictus, other 5 species of Anopheles, Culex quinquefasciatus), other Diptera (12 species of Drosophila), other insects (the cricket species Gryllus bimaculatus, the moths of the Noctuidae family Helicoverpa armigera and Heliotis viriplaca), the deer tick Ixodes scapularis, vertebrates (Human, dog, mouse), a choanoflagelate Monosiga brevicolis, a cyanobacteria Thermosynechococcus elongates, a Dermatophytes zoophilic fungus Trichophyton verrucosum and even a plant, the common plantain Plantago major. Some primer pairs are more universal than others in the sense that, for example, primer pair $\mathrm{n}^{\circ} 4$ (intron G3LEX28), primer pair $\mathrm{n}^{\circ} 11$ (intron G3LEX36 ) or primer pair $\mathrm{n}^{\circ} 21$ might amplify in 16,11 and 7 species respectively. Of all the primer pairs studied, 11 might amplify in Aedes aegypti, the main vector of dengue viruses and 15 in Culex quinquefasciatus, an annoying species also vector of human filariasis and West Nile virus (Table 3).

All the 17 loci amplified in An. pseudopunctipennis were tested for their polymorphism level using 20 An. pseudopunctipennis. Nine of the 17 amplified loci were polymorphic, ranging from two to four alleles (Table 2). 
Previous studies relying on EPIC-PCR reported that various loci might be scored for a given pair of primers $[11,32,39,40,41]$. This phenomenon may reflect former polyploidizations, tandem duplications, and other phenomena occurring during lineage evolution and producing pseudogenes. Since An. pseudopunctipennis is a diploid species, gene duplication processes are more likely involved. The simultaneous amplification of two or three loci (two for G2LEX1236 and three for GUKEX1859) can then reveal the presence of another gene or a pseudogene. These simultaneous amplifications did not seem to disturb the quality of PCRs and the reading of the genotypes because (1) the supplementary profiles did not present parasitic bands and (2) the variation of size between band systems was larger than the size polymorphism of each locus. Indeed, when intra-specific allelic variants occur, a locus can be evidenced by the presence of all the allelic combinations following a Mendelian inheritance (homozygotes and heterozygotes); if not, in order to circumvent erroneous allelic assignment, only loci where the allelic size-variation is lower between orthologous than paralogous loci, should be retained [11].

With EPIC-PCR, artifacts such as null alleles are expected to be less frequent than for example, with microsatellites [42]. However, Table 2 exhibits some differences in the number of mosquitoes that correctly responded to amplification, in particular for primer pairs $\mathrm{n}^{\circ} 6$ and 7 (Intron G3REX1037 and EX113 respectively, with 12 and 14 mosquitoes respectively instead of the 20 expected). A careful examination of results seemed to indicate the presence of null alleles for these primer pairs and moreover, no heterozygotes were encountered (Fis=1). Therefore, these two primer pairs may not be suitable for population genetic studies. The lack of amplification in two mosquitoes for primers pairs $n^{\circ} 1,2,4$ and 5 are more likely the fact of PCR manipulation problems (low DNA concentration ?) because the failure of amplification with the four above primer pairs occurred with the same two mosquitoes. Null alleles are therefore not suspected and these primer pairs may be proposed for genetic studies. 
For the small population under study, the $R^{2}$ coefficients to estimate linkage disequilibrium for each locus pair are presented in Table 4. Strong linkage disequilibrium appeared between G2REX47 and most of the other loci.

Compared with other DNA-based techniques such as microsatellites, EPICPCR is the only technique based on universal primers that allows a fast screening even for cross-species studies. Because An. pseudopunctipennis is likely a species complex [4, 5], with at least five described subspecies [43] and two recognized morphological variants in Bolivian larvae [44], the above EPIC primers may therefore be used to better understand the species status. Another interesting characteristic of EPIC -PCR is that, likely because gene duplication, one single pair of primer can produce more than one locus and can provide a number of polymorphisms, as it was the case with primer pair $n^{\circ} 3$ (intron GUKEX1859) in An. pseudopunctipennis.

Primer pairs $\mathrm{n}^{\circ} 2$ and 4 indicate (at least in the small sample of 20 mosquitoes from Mataral village) that the genotype frequencies conform to Hardy-Weinberg equilibrium. Therefore, polymorphism in these introns may be selectively neutral, as predicted for variation in most non-coding DNA sequences. If so, such markers are particularly powerful in population genetics studies.

Population genetics of An. pseudopunctipennis will benefit of the above EPIC markers, and using recently available methods [27, 42], other EPIC markers could be isolated more easily. 


\section{Disclosure of interest}

The authors declare that they have no conflicts of interest concerning this article.

\section{Acknowledgments}

This project was partly supported by a PAL+ Grant from the Ministère de la Recherche (France) and a Contrat de Développement Grant from Ministère des Affaires Etrangères (France). The participation of R. Ursic-Bedoya in this study was possible thanks to the Association of Universities and Colleges of Canada (AUCC) and its Canada-Latin America and the Caribbean Research Exchange Grants. The authors would like to thank P. Kengne who encouraged this study and an anonymous referee whose comments helped us to greatly improve the manuscript. 


\section{References}

[1] L.J. Bruce-Schwatt, Essential Malariology, $2^{\text {nd }}$ Ed, John Wiley \& Sons, New York, 1985.

[2] T.G.H. Aitken, Studies on the anopheline complex of Western America. Univ.Calif. Pub. Entomol. 7 (1945) 273-364.

[3] K.L. Knight, A. Stone, A Catalog of the Mosquitoes of the World (Diptera: Culicidae). $2^{\text {nd }}$ Ed. Vol. 6. The Thomas Say Foundation, Lanham, MD, 1977.

[4] J.G. Estrada-Franco, M.C. Ma, R.W. Gwadz, R. Sakai, G.C. Lanzaro, A. Laughinghouse, C. Galvan-Sanchez, J.L. Cespedes, R. Vargas-Sagarnaga, Evidence through crossmating experiments of a species complex in Anopheles pseudopunctipennis sensu lato: a primary malaria vector of the American continent. Am. J. Trop. Med. Hyg. 49 (1993) 746-55.

[5] M. Coetzee, J.G. Estrada-Franco, C.A. Wunderlich, R.H. Hunt, Cytogenetic evidence for a species complex within Anopheles pseudopunctipennis Theobald (Diptera: Culicidae). Am. J. Trop. Med. Hyg. 60 (1999) 649-653.

[6] S. Manguin, D.R. Roberts, E.L. Peyton, I. Fernandez-Salas, M. Barreto, R. FernandezLoayza, R. Elqueta-Spinola, R. Martinez-Granaou, M.H. Rodriguez, Biochemical systematics and population genetic structure of Anopheles pseudopunctipennis, vector of malaria in Central and South America. Am. J. Trop. Med. Hyg. 53 (1995) 362-377.

[7] E.P. Lessa, Rapid survey of DNA sequence variation in natural populations. Mol. Biol. Evol. 9 (1992) 323-330.

[8] S.R. Palumbi, C.S. Baker, Contrasting population structure from nuclear intron sequences and mtDNA of humpback whales. Mol. Biol. Evol. 11 (1994) 426-435.

[9] R.W. Slade, C. Moritz, A. Heideman, P.T. Hale, Rapid assessment of single-copy nuclear DNA variation in diverse species. Mol. Ecol. 2 (1993) 359-373. 
[10] P. Berrebi, X. Retif, F. Fang, C.G. Zhang, Population structure and systematics of Opsariichthys bidens (Osteichthyes: Cyprinidae) in south-east China using a new nuclear marker: the introns (EPIC-PCR). Biol. J. Linn. Soc. 87 (2006) 155-166.

[11] N. Hubert, F. Duponchelle, H. Nunez, R. Rivera, J.-F. Renno, Evidence of reproductive isolation among closely related sympatric species of Serrasalmus (Ostariophysii, Characidae) from the Upper Madeira River, Amazon, Bolivia. J. Fish Biol. 68 (2006) $1-21$.

[12] N. Backström, S. Fagerberg, H. Ellegren, Genomics of natural bird populations: a genebased set of reference markers evenly spread across the avian genome. Mol. Ecol. 17 (2008) 964-980.

[13] W.T. Tay, G.T. Behere, D.G. Heckel, S.F. Lee, P. Batterham, Exon-primed intron crossing (EPIC) PCR markers of Helicoverpa armigera (Lepidoptera: Noctuidae). Bull. Ent. Res. 98 (2008) 509-518.

[14] N.M. Endersby, A.A. Hoffmann, V.L. White, S. Lowenstein, S. Ritchie, P.H. Johnson, L.P. Rapley, P.A. Ryan, V.S. Nam, N.T. Yen, P. Kittiyapong, A.R. Weeks, Genetic structure of Aedes aegypti in Australia and Vietnam revealed by microsatellite and Exon Primed Intron Crossing markers suggests feasibility of local control options. J. Med. Entomol. 46 (2009) 1074-1083.

[15] J. Dixit, H. Srivastava, O.P. Singh, D.N. Saksena, A. Das, Multilocus nuclear DNA markers and genetic parameters in an Indian Anopheles minimus population. Infec. Genet. Evol. 11 (2011) 572-579.

[16] M. He, D.S. Haymer, Polymorphic intron sequences detected within and between populations of the Oriental Fruit Fly (Diptera: Tephritidae). Ann. Ent. Soc. Am. 90 (1997) 825-831. 
[17] S. Creer, A. Malhotra, R.S. Thorpe, C.E. Pook, Targeting optimal introns for phylogenetic analyses in non-model taxa: experimental results in Asian pitvipers. Cladistics 21 (2005) 390-395.

[18] S. Creer, Choosing and using introns in molecular phylogenetics. Evol. Bioinfo. 3(2007) 99-108.

[19] K.S. Wydner, J.L. Sechler, C.D. Boyd, H.C. Passmore, Use of an intron polymorphism to localize the tropoelastin gene to mouse chromosome 5 in a region of linkage conservation with human chromosome 7. Genomics 23 (1994) 125-131.

[20] Y. Yasukochi, L.A. Ashakumary, K. Baba, A. Yoshido, K. Sahara, A second generation integrated map of the silkworm reveals synteny and conserved gene order between lepidopteran insects. Genetics 173 (2006) 1319-1328.

[21] E.G. Pringle, S.W. Baxter, C.L. Webster, A. Papanicolaou, S.F. Lee, C.D. Jiggins, Synteny and chromosome evolution in the Lepidoptera: evidence from mapping in Heliconius melpomene. Genetics 177 (2007) 417-426.

[22] N. Backström, M. Brandström, L. Gustafsson, A. Qvarnström, H. Cheng, H. Ellegren. A gene-based genetic linkage map of the collared flycatcher (Ficedula albicollis) reveals extensive synteny and gene-order conservation during 100 million years of Avian evolution. Genetics 179 (2008) 1479-1495.

[23] J. Slate, J. Gratten, D. Beraldi, J. Stapley, M. Hale, J.M. Pemberton, Gene mapping in the wild with SNPs: guidelines and future directions. Genetica 136 (2009) 97-107.

[24] J.A. Wilder, H. Hollocher, Recent radiation of endemic Caribbean Drosophila of the dumni subgroup inferred from multilocus DNA sequence variation. Evolution 57 (2003) 2566-2579.

[25] A. Das, S. Mohanty, W. Stephan, Inferring the population structure and demography of Drosophila ananasae from multilocus data. Genetics 168 (2004) 1975-1985. 
[26] P. Berrebi, E. Boissin, F. Fang, G. Berrebi-Cattaneo, Intron polymorphism (EPIC-PCR) reveals phylogeographic structure of Zacco platypus in China: a possible target for aquaculture development. Heredity 94 (2005) 589-598.

[27] C. Li, J.J. Riethoven, L. Ma, Exon-primed intron crossing (EPIC) markers for non-model teleost fishes. BMC Evol. Biol. 10 (2010) 90. doi: 10.1186/1471-2148-10-90.

[28] K. Lohse, B. Sharanowski, M. Blaxter, J.A. Nicholls, G. N. Stone, Developping EPIC markers for chalcidoid Hymenoptera from EST and genomic data. Mol. Ecol. Res. 11 (2011) 521-529.

[29] R.C. Thomson, I.J. Wang, J.R. Johnson, Genome-enabled development of DNA markers for ecology, evolution and conservation. Mol. Ecol. 19 (2010) 2184-2195.

[30] N. Bierne, S.A. Lehnert, E. Bédier, F. Bonhomme, S.S. Moore, Screening for intronlength polymorphism in paenid shrimps using exon-primed intron-crossing (EPIC)PCR. Mol. Ecol. 9 (2000) 233-235.

[31] H.B.S.M. Côrte-Real, D.R. Dixon, P.W.H. Holland, Intron-targeted PCR: a new approach to survey neutral DNA polymorphism in bivalve populations. Mar. Biol. 120 (1994) 407-413.

[32] T. Atarhouch, M. Rami, G. Cattaneo-Berrebi, C. Ibanez, S. Augros, E. Boissin, A.L. Dakkak, P. Berrebi, Primers for EPIC amplification of intron sequences for fish and other vertebrate population genetic studies. BioTech. 3 (2003) 676-682.

[33] L.M. Gomulski, K. Bourtzis, S. Brogna, P.A. Morandi, C. Bonvicini, F. Sebastiani, C. Torti, C.R. Guglielmino, C. Savakis, G. Gasperi, A.R. Malacrida, Intron size polymorphism of the Adh1 gene parallels the worldwide colonization history of the Mediterranean fruit fly, Ceratitis capitata. Mol. Ecol., 7 (1998) 1729-1741. 
[34] A.J. Bohonak, N. Davies, F.X. Villablanca, G.K. Roderick, Invasions genetics of New World medflies: testing alternative colonization scenarios. Biol. Invasions 3 (2001) 103-111.

[35] J.R. Gorham, C.J. Stojanovich, H.G. Scott, Clave illustrada para los mosquitos Anofelinos de Sudamerica Occidental (Illustrated key to the Anopheline mosquitoes of Western South America). Mosq. Syst. 5 (1973) 97-156.

[36] J.K. Edwards, Miniprep procedures for the isolation of plant DNA, in: A. Karp, P. G. Issac, Ingram (eds), Molecular tools for screening biodiversity, Chapman \& Hall, London, 1998, pp.22-24.

[37] LabImage, Gel Analysis Software. Halle, Kapelan GmbH, 2005.

[38] K. Belkhir, P. Borsa, J. Goudet, L. Chikhi, F. Bonhomme, GENETIX, Logiciel sous WindowsTM pour la Génétique des Populations, Laboratoire Génome et Populations, CNRS UPR 9060. Univ.Montpellier II, Montpellier, France, 1998.

[39] M. Hassan, M. Harmelin-Vivien, F. Bonhomme, Lessepsian invasion without bottleneck: example of two rabbitfish species (Siganus rivulatus and Siganus luridus). J. Exp. Mar. Biol. Ecol. 291 (2003) 219-232.

[40] S.C. France, N. Tachino, T.F. Duda, R.A. Schleser, S.R. Palumbi, Intraspecific genetic diversity in the marine shrimp Penaeus vannamei: multiple polymorphic elongation factor-1a loci revealed by intron sequencing. Mar. Biotech. 1 (1999) 261-268.

[41] P. Borsa, A. Collet, J.-D. Durand, Nuclear-DNA markers confirm the presence of two anchovy species in the Mediterranean. C. R. Biologies 327 (2004) 1113-1123.

[42] A. Chenuil, T.B. Hoareau, E. Egea, G. Penant, C. Rocher, D. Aurelle, K. Mokhtar-Jamai, J.D.D. Bishop, E. Boissin, A. Diaz, M. Krakau, P.C. Luttikhuizen, F.P. Patti, N. Blavet, S. Mousset, An efficient method to find potentially universal genetic markers, 
applied to metazoans. BMC Evol. Biol. 10 (2010) 276. doi: 10.1186/1471-2148-10276.

[43] Walter Reed Biosystematics Unit website:

http://www.mosquitocatalog.org/taxon_descr.aspx?ID=18300

[44] F. Lardeux, T. Chavez, R. Rodriguez, L. Torrez, Anopheles of Bolivia: new records with an updated and annotated checklist. C.R. Biologies 332 (2009) 489-499. 
$\underline{\text { Table legends }}$

Table 1. The fifty four selected genes and their accession number.

Primers pairs $\mathrm{n}^{\circ} 1$ to 14 successfully amplified intron sequences in both An.

pseudopunctipennis (see also table 2) and An. gambiae (see also Fig. 1 a). Primers designed in the others genes ( $n^{\circ} 15$ to 54) did not amplify intron sequences in An. pseudopunctipennis also they did in An. gambiae (see also Fig. 1b).

Table 2. Sequences of the 14 pairs of primers which successfully amplified 17 loci from Anopheles pseudopunctipennis and their characterization.

Tm, annealing temperature in ${ }^{\circ} \mathrm{C}, H_{E}$, expected heterozygosity; $H_{O}$, observed heterosigosity, Fis, inbreeding coefficient The amplification conditions MM1 and MM2 correspond to $0.04 \mu \mathrm{M}$ and $0.4 \mu \mathrm{M}$ of primers in the master mix respectively. The overall computations for $H_{E}, H_{O}$ and Fis were carried out taking into account the polymorphic alleles only

Table 3. Primer pairs and species in which they may potentially amplify, according to nucleotide sequence alignments using BLAST (NCBI)

Table 4. $R^{2}$ coefficients for linkage disequilibrium computed for each pair of polymorphic loci. 


\section{$\underline{\text { Figure captions }}$}

\section{Figure 1. Examples of agarose gel electrophoresis results for four primer pairs}

a. Positive amplifications with An. pseudopunctipennis. The size marker (lane 8) is a $1000 \mathrm{bp}$ ladder with first band of $1000 \mathrm{bp}$ and last band of $100 \mathrm{bp}$. Lanes 7 and 14 are negative controls $\left(\mathrm{H}_{2} 0\right)$.

Lanes at the left side of the ladder correspond to results for primer pair $n^{\circ} 3$. Lanes 3 , 4, 5 are An. pseudopunctipennis, while lanes 1, 2, 6 are An. gambiae (positive controls). Lanes at the right side of the ladder correspond to results for primer 9. Lanes 11, 12, 13 are An. pseudopunctipennis while lanes 9, 10 are An. gambiae (positive controls).

b. Negative amplifications with An. pseudopunctipennis. The size marker (lane 7) is a $1000 \mathrm{bp}$ ladder first band of $1000 \mathrm{bp}$ and last band of $100 \mathrm{bp}$. Lane 6 is a negative control $\left(\mathrm{H}_{2} \mathrm{O}\right)$.

Lanes at the left side of the ladder correspond to results for primer pair $n^{\circ} 26$. Lanes 1 , 2, 3, 4 are An. pseudopunctipennis, while lane 5 is An. gambiae (positive control). Lanes at the right side of the ladder correspond to results for primer pair $\mathrm{n}^{\circ} 27$. Lanes 8, 9, 10, 11, 12, 14 are An. pseudopunctipennis while lane 13 is An. gambiae (positive control). 
Table 1

\begin{tabular}{|c|c|c|c|c|c|}
\hline $\begin{array}{l}\text { Primer } \\
\text { pair } n^{\circ}\end{array}$ & Gene & Accession number & $\begin{array}{l}\text { Primer } \\
\text { pair } n^{\circ}\end{array}$ & Gene & Accession number \\
\hline 1 & AgaP_AGAP005839 & XM_315863.4 & 28 & AgaP_AGAP011438 & XM_554781 \\
\hline 2 & AgaP_AGAP003128 & XM_001237495.2 & 29 & AgaP_AGAP011717 & XM_320795.4 \\
\hline 3 & AgaP AGAP012571 & XM_307301.3 & 30 & AgaP_AGAP010343 & XM_311599.4 \\
\hline 4 & AgaP_AGAP011936 & XM_320597.4 & 31 & AgaP_AGAP010725 & XM_559235.3 \\
\hline 5 & AgaP_AGAP001573 & XM_551238.3 & 32 & AgaP_AGAP001813 & XM_321242.4 \\
\hline 6 & AgaP_AGAP008026 & XM_555438.3 & 33 & AgaP_AGAP003857 & XM_310416.6 \\
\hline 7 & AgaP_AGAP004780 & XM_318036.4 & 34 & AgaP_AGAP004298 & XM_313573.4 \\
\hline 8 & AgaP_AGAP005961 & XM_316001.4 & 35 & AgaP_AGAP002956 & XM_311943.3 \\
\hline 9 & AgaP AGAP012014 & XM_320516.2 & 36 & AgaP_AGAP002301 & XM_312670.1 \\
\hline 10 & AgaP AGAP011363 & XM_001238009.2 & 37 & AgaP_AGAP003360 & XM_314262.4 \\
\hline 11 & AgaP_AGAP011166 & XM_309483.4 & 38 & AgaP_AGAP001407 & XM_321726.4 \\
\hline 12 & AgaP_AGAP001874 & XM_550942.3 & 39 & AgaP_AGAP003437 & XM_311723.4 \\
\hline 13 & AgaP_AGAP007887 & XM_317605.4 & 40 & AgaP AGAP007738 & XM_001689008.1 \\
\hline 14 & AgaP_AGAP009824 & XM_318932.3 & 41 & AgaP AGAP008288 & XM_001688954.1 \\
\hline 15 & AgaP_AGAP004745 & XM_318073 & 42 & AgaP AGAP009200 & XM_319976.3 \\
\hline 16 & AgaP_AGAP004934 & XM_315024.3 & 43 & AgaP_AGAP008938 & XM_319692.3 \\
\hline 17 & AgaP_AGAP005622 & XM_315632.3 & 44 & AgaP_AGAP009835 & XM_553715.3 \\
\hline 18 & AgaP_AGAP005693 & XM_315704.4 & 45 & AgaP_AGAP009785 & XM_318880.4 \\
\hline 19 & AgaP_AGAP005806 & XM_315822.4 & 46 & AgaP_AGAP009856 & XM_318967.4 \\
\hline 20 & AgaP AGAP006809 & XM_308938.4 & 47 & AgaP_AGAP004698 & XM_318145.4 \\
\hline 21 & AgaP_AGAP006825 & XM_308919.3 & 48 & AgaP_AGAP004775 & XM_318039.4 \\
\hline 22 & AgaP_AGAP007640 & XM_308229.4 & 49 & AgaP_AGAP004841 & XM_314353.3 \\
\hline 23 & AgaP_AGAP007720 & XM_574504.3 & 50 & AgaP_AGAP004717 & XM_318113.4 \\
\hline 24 & AgaP_AGAP008526 & XM_316916.3 & 51 & AgaP_AGAP004862 & XM_314327.3 \\
\hline 25 & AgaP_AGAP008527 & XM_316915.4 & 52 & AgaP_AGAP004915 & XM_315006.4 \\
\hline 26 & AgaP_AGAP012345 & XM_320207.4 & 53 & AgaP_AGAP004692 & XM_001231109.2 \\
\hline 27 & AgaP_AGAP011730 & XM_320779.3 & 54 & AgaP_AGAP005948 & XM_315983.4 \\
\hline
\end{tabular}




\section{Table 2}

\begin{tabular}{|c|c|c|c|c|c|c|c|c|c|c|c|c|}
\hline $\begin{array}{l}\text { Primer } \\
\text { pair } n^{\circ}\end{array}$ & Intron Name & Chromosome & Accession number & Primer sequences $\left(5^{\prime}-3^{\prime}\right)$ & $\begin{array}{c}T m \\
\left({ }^{\circ} \mathrm{C}\right) \\
\end{array}$ & $\begin{array}{l}\text { No. of } \\
\text { alleles }\end{array}$ & Sizes of alleles (bp) & $\begin{array}{l}\text { Amplification } \\
\text { conditions }\end{array}$ & $\begin{array}{c}\text { No. } \\
\text { mosquitoes }\end{array}$ & $H_{E}$ & $H_{O}$ & $F_{I S}$ \\
\hline 1 & G2LEX1236-1 & $2 \mathrm{~L}$ & XM_315863.4 & $\begin{array}{l}\text { F:TGGCTGGCTTCACGTCCG } \\
\text { R:CGAGTGCAGGAACGGTGA }\end{array}$ & 55 & 4 & $114,151,165,180$ & MM1 & 18 & 0.4 & 0.3 & 0.25 \\
\hline 1 & G2LEX1236-2 & $2 \mathrm{~L}$ & XM_315863.4 & $\begin{array}{l}\text { F:TGGCTGGCTTCACGTCCG } \\
\text { R:CGAGTGCAGGAACGGTGA }\end{array}$ & 55 & 1 & 297 & MM1 & 18 & - & - & - \\
\hline 2 & GUKEX1858 & $2 \mathrm{R}$ & XM_001237495.2 & $\begin{array}{l}\text { F: GCCTGTGATCGTGCGTTTCG } \\
\text { R: GGCATACCAGCAGCGTGACG }\end{array}$ & 55 & 4 & $794,857,870,876$ & MM1 & 18 & 0.3 & 0.3 & 0.09 \\
\hline 3 & GUKEX1859-1 & UNKN & XM_307301.3 & $\begin{array}{l}\text { F:CGAGGAGGGTGTACAAACGC } \\
\text { R:GGTGTCGCCTAGCTCGCCCG }\end{array}$ & 55 & 2 & 715,766 & MM1 & 20 & 0.5 & 0.7 & -0.3 \\
\hline 3 & GUKEX1859-2 & UNKN & XM_307301.3 & $\begin{array}{l}\text { F:CGAGGAGGGTGTACAAACGC } \\
\text { R:GGTGTCGCCTAGCTCGCCCG }\end{array}$ & 55 & 2 & 306,320 & MM1 & 20 & 0.1 & 0.1 & 0.65 \\
\hline 3 & GUKEX1859-3 & UNKN & XM_307301.3 & $\begin{array}{l}\text { F:CGAGGAGGGTGTACAAACGC } \\
\text { R:GGTGTCGCCTAGCTCGCCCG }\end{array}$ & 55 & 3 & $183,193,197$ & MM1 & 20 & 0.2 & 0.1 & 0.79 \\
\hline 4 & G3LEX28 & $3 \mathrm{~L}$ & XM_320597.4 & $\begin{array}{l}\text { F:CCAACTACTCGGCCGTGC } \\
\text { R:GCCGGCCATCTCCTTCGC }\end{array}$ & 60 & 3 & $246,253,261$ & MM2 & 18 & 0.4 & 0.4 & 0.02 \\
\hline 5 & G2REX47 & $2 \mathrm{R}$ & XM_551238.3 & $\begin{array}{l}\text { F:GGCACGGTGGGGAAGACG } \\
\text { R:CCGTCCACCACCATCGGG }\end{array}$ & 60 & 4 & $220,228,257,273$ & MM2 & 18 & 0.3 & 0.4 & -0.1 \\
\hline 6 & G3REX1037 & $3 R$ & XM_555438.3 & $\begin{array}{l}\text { F:GCAAACGCGAAAGAACCG } \\
\text { R:GCCTGGTAGCGCTTCTCG }\end{array}$ & 60 & 4 & $281,315,345,405$ & MM2 & 12 & 0.5 & 0 & 1 \\
\hline 7 & EX113 & $2 \mathrm{~L}$ & XM_318036.4 & $\begin{array}{l}\text { F:CATCTATCTGCTGAACTCGC } \\
\text { R:CGTCGGTCACATTCCACATC }\end{array}$ & 60 & 3 & $541,557,574$ & MM2 & 14 & 0.4 & 0 & 1 \\
\hline 8 & EX1358 & $2 \mathrm{~L}$ & XM_31600104 & $\begin{array}{l}\text { F:CATGCCTCCAATGGTGCC } \\
\text { R:CCGTACGTTCCTTCGCCA }\end{array}$ & 60 & 1 & 249 & MM2 & 20 & - & - & - \\
\hline 9 & G3LEX3 & $3 \mathrm{~L}$ & XM_320516.2 & $\begin{array}{l}\text { F:CCGAAGATGAGCTCAGAGATGC } \\
\text { R:CCTAGCTTGTCGGTGATTTCTG }\end{array}$ & 55 & 1 & 185 & MM1 & 20 & - & - & - \\
\hline 10 & G3LEX9 & $3 \mathrm{~L}$ & XM_001238009.2 & $\begin{array}{l}\text { F:CGCCCTGCCTGGCATGGATTCG } \\
\text { R:GCAGGCACAGCCACCTTCCGGG }\end{array}$ & 55 & 1 & 656 & MM1 & 20 & - & - & - \\
\hline 11 & G3LEX36 & $3 \mathrm{~L}$ & XM_309483.4 & $\begin{array}{l}\text { F:CGCGGCAATCATGAGTGCGCC } \\
\text { R: CCACCGGCAGACAGTTGAAGC }\end{array}$ & 55 & 1 & 191 & MM1 & 20 & - & - & - \\
\hline 12 & G2REX46 & $2 \mathrm{R}$ & XM_550942.3 & $\begin{array}{l}\text { F:CCGACGATAGAGGACAGC } \\
\text { R:GTTGAAGGTCGACTGTGC }\end{array}$ & 60 & 1 & 497 & MM2 & 20 & - & - & - \\
\hline 13 & G3REX491 & $3 \mathrm{R}$ & XM_317605.4 & $\begin{array}{l}\text { F:CGTTGGAGCAGCAACAACAGC } \\
\text { R:GGTAATGATTCCTGATATTGC }\end{array}$ & 55 & 1 & 136 & MM2 & 20 & - & - & - \\
\hline \multirow[t]{2}{*}{14} & G3REX1062 & $3 R$ & XM_318932.3 & $\begin{array}{l}\text { F:CGATCTGCTGGCCGACTTCC } \\
\text { R:CCATCGCCCTTGCGCTCACC }\end{array}$ & 55 & 1 & 177 & MM1 & 20 & - & - & - \\
\hline & & & & & & & & & Overall* & 0.35 & 0.24 & 0.35 \\
\hline
\end{tabular}




\section{Table 3}

Primer pair $\mathrm{n}^{\circ}$

\begin{tabular}{|c|c|c|c|c|c|c|c|c|c|c|c|c|c|c|c|c|c|c|c|c|c|c|c|c|c|c|c|}
\hline \multirow[b]{2}{*}{ Especie } & & \multirow[b]{2}{*}{$\begin{array}{l}\text { number or primer } \\
\text { pairs that might } \\
\text { amplify in the species }\end{array}$} \\
\hline & 1 & 2 & 4 & 8 & 9 & 10 & 11 & 12 & 13 & 14 & 16 & 18 & 19 & 20 & 21 & 22 & 29 & 31 & 34 & 35 & 36 & 37 & 38 & 43 & 50 & 56 & \\
\hline Aedes aegypti & $\mathrm{x}$ & $\mathrm{x}$ & $\mathrm{x}$ & & $\mathrm{x}$ & $\mathrm{x}$ & & & & $\mathrm{x}$ & & & $\mathrm{x}$ & & $\mathrm{x}$ & & $\mathrm{x}$ & $\mathrm{x}$ & & & & & $\mathrm{x}$ & & & & 11 \\
\hline Ae. albopictus & & & & & & & & & & & & & & $\mathrm{x}$ & & & & & & & & & & & & & 1 \\
\hline Anopheles arabiensis & & & & & & & & & & & $\mathrm{x}$ & $\mathrm{x}$ & & & & & & & & & & & & & & & 2 \\
\hline An. bwambae & & & & & & & & & & & & $\mathrm{x}$ & & & & & & & & & & & & & & & 1 \\
\hline An. christyi & & & & & & & & & & & & $\mathrm{x}$ & & & & & & & & & & & & & & & 1 \\
\hline An. merus & & & & & & & & & & & & $\mathrm{x}$ & & & & & & & & & & & & & & & 1 \\
\hline An. quadrianulatus & & & & & & & & & & & & $\mathrm{x}$ & & & & & & & & & & & & & & & 1 \\
\hline An. stephensi & & & & & & & & & & & & & & & & & & & & & & & & & & $\mathrm{x}$ & 1 \\
\hline Canis familiaris & & & & & & & $\mathrm{x}$ & & & & & & & & & & & & & & & & & & & & 1 \\
\hline Culex quinquefasciatus & & $\mathrm{x}$ & $\mathrm{x}$ & $\mathrm{x}$ & & $\mathrm{x}$ & $\mathrm{x}$ & & & $\mathrm{x}$ & $\mathrm{x}$ & & $\mathrm{x}$ & $\mathrm{x}$ & $\mathrm{x}$ & $\mathrm{x}$ & & $\mathrm{x}$ & $\mathrm{x}$ & & & $\mathrm{x}$ & & & & $\mathrm{x}$ & 15 \\
\hline Drosophila melanogaster & & & $\mathrm{x}$ & & & & $\mathrm{x}$ & & & & & & & & $\mathrm{x}$ & & & $\mathrm{x}$ & $\mathrm{x}$ & & $\mathrm{x}$ & $\mathrm{x}$ & & $\mathrm{x}$ & & & 8 \\
\hline D. ananassae & & & $\mathrm{x}$ & & & & $\mathrm{x}$ & & & & & & & & $\mathrm{x}$ & $\mathrm{x}$ & & & & & & & & & & & 4 \\
\hline D. erecta & & & $\mathrm{x}$ & & & & & & & & & & & & $\mathrm{x}$ & & & & & & $\mathrm{x}$ & $\mathrm{x}$ & & & & & 4 \\
\hline D. grimshawi & & & $\mathrm{x}$ & & $\mathrm{x}$ & & $\mathrm{x}$ & & & & & & & & $\mathrm{x}$ & & & & & & & & & & & & 4 \\
\hline D. mojavensis & & & $\mathrm{x}$ & & & & $\mathrm{x}$ & & & & & & & & $\mathrm{x}$ & & & & & & & & & & & & 3 \\
\hline D. persimilis & & & $\mathrm{x}$ & & & & $\mathrm{x}$ & & & & & & & & & & $\mathrm{x}$ & & & & & & & & & & 3 \\
\hline D. pseudoobscura & & & $\mathrm{x}$ & & & & $\mathrm{x}$ & & & & & & & & & & $\mathrm{x}$ & & & & & & & & & & 3 \\
\hline D. sechellia & & & $\mathrm{x}$ & & & & $\mathrm{x}$ & & & & & & & & & & & & & & $\mathrm{x}$ & $\mathrm{x}$ & & & & & 4 \\
\hline D. simulans & & & $\mathrm{x}$ & & & & $\mathrm{x}$ & & & & & & & & & & & & & & & $\mathrm{x}$ & & & & & 3 \\
\hline D. virilis & & & & & & & & & $\mathrm{x}$ & & & & & & & & & & & & & & & & & & 1 \\
\hline D. willistoni & & & & & & & & & $\mathrm{x}$ & & & & & & & & & & & & & & & & & & 1 \\
\hline D. yakuba & & & $\mathrm{x}$ & & & & & & $\mathrm{x}$ & & & & & & & & & & $\mathrm{x}$ & & $\mathrm{x}$ & $\mathrm{x}$ & & $\mathrm{x}$ & & & 6 \\
\hline Gryllus bimaculatus & & & $\mathrm{x}$ & & & & & & & & & & & & & & & & & & & & & & $\mathrm{x}$ & & 2 \\
\hline Helicoverpa armigera & & & $\mathrm{x}$ & & & & & & & & & & & & & & & & & & & & & & & & 1 \\
\hline Heliotis viriplaca & & & $\mathrm{x}$ & & & & & & & & & & & & & & & & & & & & & & & & 1 \\
\hline Homo sapiens & & & & & & $\mathrm{x}$ & & & & & & & & & & & $\mathrm{x}$ & & & & & & & & & & 2 \\
\hline Ixodes scapularis & & & $\mathrm{x}$ & & & $\mathrm{x}$ & $\mathrm{x}$ & & & & & & & & & & & $\mathrm{x}$ & & & & & & & & & 4 \\
\hline Monosiga brevicolis & & & & & & & & $\mathrm{x}$ & $\mathrm{x}$ & & & & & & & & & & & & & & & & & & 2 \\
\hline Mus musculus & & & & & & & & & & & & & & & & & & & $\mathrm{x}$ & & & & & & & & 1 \\
\hline Plantago major & & & & & & & & & & & & & & & & & & & & $\mathrm{x}$ & & & & & & & 1 \\
\hline Thermosynechococcus elongatus & & & & & & & & & & & & & & & & & & & & & & & & & $\mathrm{x}$ & & 1 \\
\hline Trichophyton verrucosum & & & & & & $\mathrm{x}$ & & & & & & & & & & & & & & & & & & & & & 1 \\
\hline
\end{tabular}

Number of species that might be

1216

$5 \quad 11$ 
Table 4.

\begin{tabular}{|c|c|c|c|c|c|c|c|c|}
\hline Intron names & G2LEX1858 & GUKEX1859-1 & GUKEX1859-2 & GUKEX1859-3 & G3LEX28 & G2REX47 & G3REX1037 & EX113 \\
\hline G2LEX1236-1 & 0.28 & 0.42 & 0.65 & 0.01 & 0.10 & 0.91 & 0.78 & 0.04 \\
\hline G2LEX1235-1 & & 0.79 & 0.92 & 0.74 & 0.62 & 0.21 & 0.59 & 0.89 \\
\hline GUKEX1859-1 & & & 0.30 & 0.30 & 0.29 & 0.85 & 0.71 & 0.20 \\
\hline GUKEX1859-2 & & & & 0.96 & 0.67 & 0.89 & 0.83 & - \\
\hline GUKEX1859-3 & & & & & 0.10 & 0.99 & 0.06 & 0.10 \\
\hline G3LEX28 & & & & & & 0.90 & 0.21 & 0.01 \\
\hline G2REX47 & & & & & & & 0.02 & 0.52 \\
\hline G3REX1037 & & & & & & & & - \\
\hline
\end{tabular}


Figure 1.

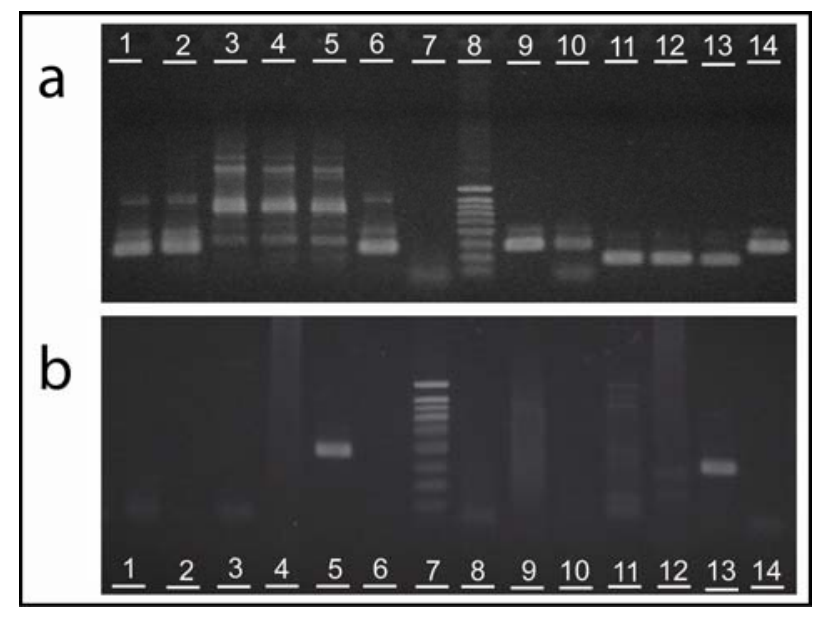

